\title{
APPROACHES TO DEVELOPING AND IMPLEMENTING CLINICAL AND ORGANIZATIONAL REGULATIONS ENSURING INFECTIOUS SAFETY AND EPIDEMIOLOGICAL RESPONSE IN THE WORK PROCESS (THE CASE OF COVID-19)
}

D0I: 10.36740/WLek202103233

\author{
Dmytro D. Dyachuk, Oleg L. Zyukov, Olena 0. Oshyvalova, Yuriy B. Yashchenko, Olena M. Lishchyshyna \\ STATESCIENTIFIC INSTITUTION"RESEARCH AND PRACTICAL CENTRE OF PREVENTIVE AND CLINICAL MEDICINE"OF THE STATE ADMINISTRATION, KYIV, UKRAINE
}

\begin{abstract}
The aim: Of the work was to develop clinical and organizational regulations ensuring infectious safety and epidemiological response in the work process (the case of COVID-19) based on the current legislative acts of Ukraine to combat the spread of coronavirus disease (COVID-19), as well as on the data from international practices.

Materials and methods: The research objective was carried out in accordance with the Methodology for the development of medical and technological documents for the standardization of medical care.

Results: The Protocol includes organizational elements to prevent the spread of coronavirus disease, such as "The development of general provisions on infectious safety and antiepidemic measures during the COVID-19 pandemic in the company's workplaces, taking into account the legislative acts of Ukraine and international practices", which include: the development of "Health Questionnaire" (epidemiological data questionnaire) for daily monitoring of the company employee health; the development of "Checklist for self-assessment of the workplace", "Checklist for self-assessment of the public space"; the development of "Analytical report on compliance with the infectious safety rules in the workplace and in the public space on the basis of self-assessment", thirteen Appendices.

Conclusions: "The Protocol for infectious safety and antiepidemic measures in the work process" is a detailed instruction that provides a balance of compliance with medical standards and reasonable needs of employees and employers through the implementation of scientific evidence base in antiepidemic and infectious safety measures in the workplace.
\end{abstract}

KEY WORDS: Protocol, infectious safety, antiepidemic measures, work process, COVID-19

Wiad Lek. 2021;74(3 p.ll):741-745

\section{INTRODUCTION}

One of the key principles of health care is the provision of medical aid in accordance with the standards of evidence-based medicine. In the present context of the development of our state, standardization plays a leading role in the system of management tools for quality control in public health care $[1,2]$. The state has identified the development of standardization as one of the priority areas of health care reform in Ukraine and annually provides supplements and updates to the legal and regulatory framework for standardization administration [1, 3-5].

The outbreak of a new coronavirus disease (COVID-19) is accompanied by uncertainty about the main epidemiological, clinical, virological characteristics of the new pathogen and especially its ability to spread among the population and its virulence (disease severity). Currently, data on the epidemiology, clinical features, prevention and treatment of this disease are updated almost every day [610]. The urgency of counteracting the spread of coronavirus disease issues challenges to healthcare professionals related to rapid diagnosis and timely provision of medical aid to patients, as well as to ensuring sufficient level of infectious safety in the workplace.
The COVID-19 pandemic has become the defining challenge not only for the Ukrainian health system, but also for employers who are concerned about personnel infectious safety in the workplace. Enterprises and organizations that resume work have to implement measures on minimizing the spread of infectious diseases during the epidemic.

\section{THE AIM}

The aim of the work was to develop organizational tool for ensuring infectious safety and antiepidemic measures in the work process (the case of COVID-19) and to establish its effectiveness in early detection of coronavirus disease (COVID-19) in the working environment.

\section{MATERIALS AND METHODS}

The study was designed and performed at the State Scientific Institution "Scientific and Practical Center for Preventive and Clinical Medicine" of the State Administration (hereinafter referred to as SSI "SPC PCM" SA).

The research objective was carried out in accordance with the Methodology for the development of medical 
and technological documents for the standardization of medical care $[4,11,12]$. The Protocol form as a regional statutory document aimed at ensuring the provision of infectious safety services and medical care in certain infectious diseases was used $[1,2,5]$.

The content of the Protocol provisions was developed in accordance with the current legislative acts of Ukraine [3$10,11,13-15]$ and data from modern scientific literature on relevant issues of COVID-19 prevention. The international guidelines on the features of organizing a safe working process, countering the spread of coronavirus disease (COVID-19) in the working environment were analyzed using analytical and systematic approach methods [16-20]. The provisional results of our study on the development of local health care protocols (clinical pathways) were used in modeling [21,22].

\section{RESULTS}

The main tasks in the development of the Protocol involved the control of infectious diseases during production, assignment of authority between the employer, employees and medical personnel who provide primary, emergency and specialized (tertiary) medical care.

The Protocol is presented on 53 pages and has the following structure: title page, writing group, table of contents, organizational, production and final stages and description of the activities of each stage, appendices, instructions and registers to the Protocol.

The Protocol includes organizational elements to prevent the spread of coronavirus disease, such as "The development of general provisions on infectious safety and antiepidemic measures during the COVID-19 pandemic in the company's workplaces, taking into account the legislative acts of Ukraine and international practices", which include: the development of "Health Questionnaire" (epidemiological data questionnaire) for daily monitoring of the company employee health; the development of "Checklist for self-assessment of the workplace", "Checklist for self-assessment of the public space"; the development of "Analytical report on compliance with the infectious safety rules in the workplace and in the public space on the basis of self-assessment"; the development of instructions on compliance with the infectious safety rules by the company staff, taking into account the possible risks of spreading coronavirus infection SARS-CoV-2.

It should be noted that at each stage of the Protocol, preventive measures for the disease spread are taken into account, namely ensuring the safety of workers and medical staff: compliance with the rules of personal protection and rational use of personal protective equipment (PPE) (according to Appendix 6 "Rational use of personal protective equipment in case of COVID-19" and Appendix 7 "Infection prevention and control measures during the provision of medical care to a patient whose case is defined as COVID-19" of the Standards of medical care "Coronavirus disease (COVID-19)" approved by the Order of the Ministry of Health Of Ukraine No.722 of 28.03.2020) [6].
The organizational stage also includes "Coordination of provisions on hygiene and infection control, collection and disposal of PPE, public catering rules" by the employer, namely: conducting a marketing search and concluding an agreement for the purchase of personal protective equipment for the company's employees, creating a permanent irreducible minimum level of supply of PPE; calculation of the need for personal protective equipment for the company's employees in accordance with the specification approved by the Order of the Ministry of Health of Ukraine No.2122 of 17.09.20 "On amendments to the Standards of medical care "Coronavirus disease (COVID-19)"; conducting a marketing search and concluding an agreement on the disposal of used PPE; development of requirements for the collection and disposal of used PPE; conducting a marketing search and concluding an agreement with a cleaning company to ensure hygiene and infection control at the company's workplaces during the COVID-19 pandemic; development of requirements for hygiene and infection control at the company's workplaces during the COVID-19 pandemic; development of requirements for the provision of public catering services during the COVID-19 pandemic.

The preparatory stage also envisages creating personnel's awareness of the safety rules and adaptive quarantine, namely instructing the personnel responsible for the internal control on the implementation of general provisions, instructions on infectious safety; placement in the workplace of information posters on the symptoms of coronavirus disease (COVID-19), mandatory use of PPE, compliance with quarantine rules.

The maintenance stage of the production process provides for common antiepidemic measures with a multiplicity that meets the requirements of the Resolution of the Cabinet of Ministers of Ukraine No.641 of 22.07.2020 "On the establishment of quarantine and the introduction of enhanced antiepidemic measures in the area with a significant spread of acute respiratory disease COVID-19 caused by coronavirus SARS-CoV-2" [15].

Common antiepidemic measures provided by the Protocol are as follows: before-doctor examination of the employees before the start of the working day (thermometry) and identification of individuals for additional examination; conducting employee surveys and submitting employee questionnaires to the supervising physician on a daily basis; analyzing employee questionnaires and identifying individuals for additional examination; internal control of compliance with instructions on infectious safety by employees in the workplace.

The Protocol includes a number of measures on internal control of the required level of hygiene and infection control and rules of public catering, collection of PPE on the territory of the company, which is carried out by the authorized personnel of the company: internal control of compliance with the disinfection cycle and the cleaning schedule at workplaces and in the public space; internal control of compliance with the infectious safety rules in public catering; internal control of the collection and 
disposal of used PPE; weekly analysis of the results of internal control.

The Protocol provides for screening and ongoing examinations of the company's employees for infection (e.g. COVID-19). The set of necessary medical services is provided by a medical institution within the framework of a contractual relationship and may include: conducting a preventive examination of employees by a GP or a family medical doctor for early detection of ARVI; before-doctor examination of the employees (questionnaires, thermometry); collecting samples from the nasopharynx for SARSCov-2 virus detection by PCR; blood sampling for the detection of Ig M, Ig G antibodies by ELISA; laboratory testing; assessment of the examination/survey findings and registration of admission to the workplaces for the company's employees.

When a confirmed case of COVID-19 disease is detected, the Protocol provides for all necessary medical services recommended in a particular case and approved by the Resolution of the Cabinet of Ministers "Coronavirus disease (COVID-19)" taking into account the severity of the course. The Protocol also includes antiepidemic measures in case of contact.

If the company carries out a certain amount of work in time, then at the final stage of the Protocol implementation, the final act of the health status of the company's employees is issued and the responsible person of the company provides an analytical report on compliance with the infection safety rules at workplaces; hygiene and infection control; collection and disposal of used PPE; public catering rules for the period of implementation of work.

Thirteen Appendices have been prepared to the Protocol based on the current statutory documents $[1,2,15]$ and international practices [16-20]:

Appendix 1. Common antiepidemic measures and provisions for infectious safety.

Appendix 2. Covid-19 epidemiological questionnaire for employees(in Ukrainian and English).

Appendix 3. Checklist for self-assessment of compliance with the infectious safety rules in the workplace.

Appendix 4. Checklist for self-assessment of compliance with the infectious safety rules in the public space.

Appendix 5. Analytical report on compliance with the infectious safety rules in the workplace and in the public space on the basis of self-assessment.

Appendix 6. Instructions for personnel at each workplace on compliance with the infectious safety rules.

Appendix 7. Requirements plan for personal protective equipment.

Appendix 8. Instructions for the collection and disposal of personal protective equipment.

Appendix 9. Cleaning/processing instruction.

Appendix 10. Cleaning and disinfection schedule.

Appendix 11. Instructions for personnel on compliance with the infectious safety rules in public catering.

Appendix 12. Report of personnel screening examination (routine, opportunistic).

Appendix 13. Report on the results of examination.

\section{DISCUSSION}

Thus, "The Protocol for infectious safety and antiepidemic measures in the work process" is a detailed instruction that provides a balance of compliance with medical standards and reasonable needs of employees and employers through the implementation of scientific evidence base in antiepidemic and infectious safety measures in the workplace.

"The Protocol for infectious safety and antiepidemic measures in the work process" was approved in the working environment during the preparatory and shooting periods of film production from 20.07.20 to 06.10.20. Medical workers of the SSI "SPC PCM" SA examined 358 individuals of the organized contingents on work days of the enterprise in accordance with the provisions of the Protocol, namely: daily monitoring of the employees' clinical state, collecting samples from the nasopharynx for SARS-Cov- 2 virus detection by polymerase chain reaction, studying the level of Ig M, Ig G antibodies to SARS-CoV-2 by enzyme-linked immunosorbent assay.

The high effectiveness of the organizational tool is shown by the detection of 19 cases of coronavirus disease (COVID -19), which amounted to $5.3 \%$ of the total number of employees, including asymptomatic disease in 6 people $(1.7 \%)$ and early manifestations of coronavirus disease (COVID-19) in 13 people (3.6\%). It should also be noted that the implementation of antiepidemic measures helped timely localize the sites of the disease and prevent its spread among the employed persons, as evidenced by the absence of patients among the contact personnel.

\section{CONCLUSIONS}

It is the first time the organizational tool "The Protocol for infectious safety and antiepidemic measures in the work process" has been developed and its effectiveness has been evaluated, which allows recommending its implementation for employers and health care institutions in the absence of the relevant approved medical and technological document of the state standard.

The developed Protocol is a new clinical and organizational document, which is a tool for social and clinical administration with the ability to manage updates in accordance with modern scientific evidence, and is the basis of an integrated approach in health care.

The continuous update of the regulatory framework of medical care to patients with suspected COVID-19 requires constant updating of the provisions and measures of the Protocol with further assessment of the quality of antiepidemic measures.

\section{REFERENCES}

1. Seniuta I. Ya. Novi pidkhody do standartiv yakosti nadannia medychnoi dopomohy ta yikh mozhlyvi yurydychno-pravovi naslidky [New approaches to the quality standards of medical care and their possible legal consequences]. Ukrainskyi medychnyi chasopys. 2017. http:// www.umj.com.ua/article/108196/novi-pidhodi-do-standartiv-yakostinadannya-medichnoyi-dopomogi-ta-yih-mozhlivi-yuridichno-pravovinaslidki. (In Ukrainian). 
2. Yarosh N.P. Normatyvno-pravove rehuliuvannia rozvytku standartyzatsii u sferi okhorony zdorovia naselennia Ukrainy [Normative-legal regulation of standardization development in the sphere of public health protection of Ukraine]. Ekonomika i pravo okhorony zdorovia. 2016; 2: 76 - 80. (In Ukrainian).

3. Kulhynskyi E. Kontseptsyia hosudarstvennoho upravlenyia kachestvom medytsynskoi pomoshchy v sfere zdravookhranenyia Ukraynu [The concept of state management of the quality of medical care in the field of health care in Ukraine]. Administrarea Publică. 2016; 3: 94-103. (In Russian).

4. Nakaz MOZ Ukrainy vid 28 veresnia 2012 roku №751 «Pro stvorennia ta vprovadzhennia medyko-tekhnolohichnykh dokumentiv zi standartyzatsii medychnoi dopomohy v systemi Ministerstva okhorony zdorovia Ukrainy» (redaktsiia vid 02.11.2018r.) [Order of the Ministry of Health of Ukraine dated September 28, 2012 №751 «0n the creation and implementation of medical and technological documents for the standardization of medical care in the system of the Ministry of Health of Ukraine».(In Ukrainian).

5. Nakaz M0Z Ukrainy 29 hrudnia 2016 roku № 1422 «Pro vnesennia zmin do nakazu Ministerstva okhorony zdorovia Ukrainy vid 28 veresnia 2012 roku №751» [5. Order of the Ministry of Health of Ukraine of December 29, 2016 № 1422"0n Amendments to the Order of the Ministry of Health of Ukraine of September 28, 2012 №751"]. (In Ukrainian).

6. Nakaz MOZ Ukrainy vid 28 bereznia 2020 r. №722 «Orhanizatsiia nadannia medychnoi dopomohy khvorym na koronovirusnu khvorobu (COVID 19)» [Order of the Ministry of Health of Ukraine of March 28, 2020 №722"Organization of medical care for patients with coronavirus disease (COVID 19)"]. (In Ukrainian).

7. Nakaz MOZ Ukrainy vid 02 kvitnia 2020 r. №762 «Pro zatverdzhennia protokolu «Nadannia medychnoi dopomohy dlia likuvannia koronavirusnoi khvoroby (COVID-19)» [Order of the Ministry of Health of Ukraine of April 2, 2020 №762 "On approval of the protocol"Provision of medical care for the treatment of coronavirus disease (COVID-19) "]. (In Ukrainian).

8. Nakaz M0ZUkrainy vid 09 kvitnia 2020 r. №827 «Pro vnesennia zmin do nakazu Ministerstva Ustinov 0.V. Standartyzatsiia nadannia medychnoi dopomohy v Ukraini: suchasnyi stan problem [Standardization of medical care in Ukraine: the current state of the problem]. Ukrainskyi medychnyi chasopys. 2014; 2(100). (In Ukrainian).

9. Nakaz M0Z Ukrainy vid 10 kvitnia 2020 r. №852 «Pro vnesennia zmin do protokolu «Nadannia medychnoi dopomohy dlia likuvannia koronavirusnoi khvoroby (COVID 19)» [Order of the Ministry of Health of Ukraine of April 10, 2020 №852 "On Amendments to the Protocol" Provision of medical care for the treatment of coronavirus disease (COVID 19)“]. (In Ukrainian).

10. Nakaz MOZ Ukrainy vid 23 kvitnia 2020 r. №953 «Pro vnesennia zmin do nakazu Ministerstva okhorony zdorovia Ukrainy vid 28 bereznia 2020 roku №722» [Order of the Ministry of Health of Ukraine of April 23, 2020 №953 «0n Amendments to the Order of the Ministry of Health of Ukraine of March 28, 2020 №722»)]. (In Ukrainian).

11. lermolova Yu. V. Lokalni protokoly — osnova systemy standartyzatsii medychnoi dopomohy [Local protocols - the basis of the system of standardization of medical care]. Ukrainskyi medychnyi chasopys. 2012. https://www.umj.com.ua/article /24170/lokalni-protokoli-osnovasistemi-standartizacii-medichnoi-dopomogi. (In Ukrainian).

12. Ustinov 0. V. Standartyzatsiia nadannia medychnoi dopomohy v Ukraini: suchasnyi stan problem [Standardization of medical care in Ukraine: the current state of the problem]. Ukrainskyi medychnyi chasopys. 2014;
2(100). https://www.umj.com.ua/ article/72108/ standartizaciyanadannya-medichnoi-dopomogi-v-ukraini-suchasnij-stan-problemi. (In Ukrainian).

13. Ihnatieva H. F. Standartyzatsiia medychnoi dopomohy yak faktor sotsializatsii derzhavnykh upravlinskykh posluh [Standardization of medical care as a factor in the socialization of public administration services]. http://academy.gov.ua/ej/ej6/txts/ 07igfsas.htm. (In Ukrainian).

14. Postanova Kabinetu Ministriv Ukrainy vid 11 bereznia 2020 r. №211 «Pro zapobihannia poshyrenniu na terytorii Ukrainy koronavirusu COVID-19» [Resolution of the Cabinet of Ministers of Ukraine of March 11, 2020 №211 "On prevention of the spread of coronavirus COVID-19 in Ukraine"] https://chernigiv-rada.gov.ua/news/id-42234/ . (In Ukrainian).

15. Postanova Kabinetu Ministriv Ukrainy vid 22 lypnia 2020r. №641 «Pro vstanovlennia karantynu ta zaprovadzhennia posylenykh protyepidemichnykh zakhodiv na terytorii iz znachnym poshyrenniam hostroi respiratornoi khvoroby COVID-19, sprychynenoi koronavirusom SARS-CoV-2» [Resolution of the Cabinet of Ministers of Ukraine of July 22, 2020 №641 «0n the establishment of quarantine and the introduction of enhanced anti-epidemic measures in the area with a significant spread of acute respiratory disease COVID-19 caused by coronavirus SARS-CoV-2»]. (In Ukrainian).

16. Clinical management of severe acute respiratory infection when novel coronavirus (2019-nCoV) infection is suspected Interim guidance 28 January 2020. 2020. https://www.who.int/publicationsdetail/ clinical-management-of-severe-acute-respiratory-infection-whennovelcoronavirus-(ncov)-infection-is-suspected.

17. «Coronavirus Disease 2019 (COVID-19) Treatment Guidelines». 2020. https://www.covid19treatmentguidelines.nih.gov/.

18. Novel Coronavirus (2019-nCoV) technical guidance: Early investigations. 2020. https://www.who.int/emergencies/diseases/novelcoronavirus-2019/technicalguidance.

19. Novel Coronavirus (2019-nCoV) v2 Operational Support \& Logistics. 2020. https://www.who.int/docs/default-source/coronaviruse/ situation-reports/20200203-sitrep-14-ncov.pdf?sfvrsn=f7347413_4.

20. WH0. 2019-nCoV. SurveillanceGuidance. 2020.3 Global Surveillance for human infection with novel coronavirus (2019-nCoV) Interim guidance v3 31 January 2020. 2020. https://www.who.int/publications-detail/ global-surveillance-for-human-infectionwith-novel-coronavirus(2019-ncov).

21. Oshyvalova 0.0. Klinichnyi marshrut patsiienta z peredonkolohichnoiu patolohiieiu shkiry [Clinical route of a patient with pre-oncological skin pathology]. Ukrainskyi zhurnal dermatolohii ta venerolohii. 2016;3(62): 64-68. (In Ukrainian).

22. Oshyvalova 0.0. Rozrobka ta vprovadzhennia lokalnykh protokoliv nadannia medychnoi dopomohy khvorym na peredonkolohichnu patolohiiu shkiry. Materialy naukovo-praktychnoi konferentsii z mizhnarodnoiu uchastiu «Suchasni pidkhody do formuvannia klinichnykh nastanov z diahnostyky i likuvannia shkirnykh zakhvoriuvan ta infektsii, shcho peredaiutsia statevym shliakhom: yevropeiskyi dosvid ta ukrainski realii» [Development and implementation of local protocols for providing medical care to patients with pre-oncological skin pathology. Proceedings of the scientific-practical conference with international participation «Modern approaches to the formation of clinical guidelines for the diagnosis and treatment of sexually transmitted diseases and infections: European experience and Ukrainian realities»], 19-20 zhovtnia, 2016r. Ternopil, 2016; 1:100. (In Ukrainian). 
Title of the research topic: "Scientific substantiation of creating a qualitatively new system of prevention of non-communicable diseases and improving the model of managed medical care at the level of multidisciplinary health care institution in the functioning of a single medical information system" № state registration 0119 U001147.

\section{ORCID and contributionship:}

Dmytro D. Dyachuk: 0000-0003-4583-4909 ${ }^{A, E, F}$

Oleg L. Zyukov: 0000-0001-7954-1448 ${ }^{A, E, F}$

Olena O. Oshyvalova: 0000-0002-0395-0269 ${ }^{B, C, D}$

Yuriy B. Yashchenko: 0000-0003-1790-6725 ${ }^{\text {A, F }}$

Olena M. Lishchyshyna: 0000-0002-7455-8854 ${ }^{A, F}$

\section{Conflict of interest:}

The Authors declare no conflict of interest.

\section{CORRESPONDING AUTHOR}

Olena 0.0 shyvalova

State Scientific Institution "Research and Practical

Centre of Preventive and Clinical Medicine

5, Verhnyaya St., Kyiv 04012, Ukraine

tel: +38 (044) 2546441

e-mail: oshivalovaea@gmail.com

Received: 25.12 .2020

Accepted: 01.03.2021

A - Work concept and design, B - Data collection and analysis, C - Responsibility for statistical analysis,

D-Writing the article, $\mathbf{E}$-Critical review, $\mathbf{F}$ - Final approval of the article 